\title{
Multimedia of Number Recognition for Early Childhood Using Image Object
}

\author{
Janner Simarmata ${ }^{1}$, Tonni Limbong ${ }^{2}$, ARS Tambunan ${ }^{1}$, Mariati Purnama Simanjuntak ${ }^{1}$, Riswan Limbong ${ }^{3}$, \\ Nirmala Purba ${ }^{7}$, Fricles Ariwisanto Sianturi ${ }^{8}$, Pilippus Tarigan', Efendi Napitupulu' \\ ${ }^{1}$ Universitas Negeri Medan, Medan, Indonesia \\ ${ }^{2}$ Universitas Katolik Santo Thomas, Medan, Indonesia \\ ${ }^{3}$ STMIK Budi Darma, Medan, Indonesia \\ ${ }^{4}$ Bina Nusantara Institute of Creative Technology Malang, Malang, Indonesia \\ ${ }^{5}$ Universitas Wijaya Kusuma Surabaya, Surabaya, Indonesia \\ ${ }^{6}$ MAN Sidoarjo, Sidoarjo, Indonesia \\ ${ }^{7}$ Universitas Asahan, Kisaran, Indonesia \\ ${ }^{8}$ STMIK Pelita Nusantara, Medan, Indonesia \\ ${ }^{9}$ STMIK Kristen NEUMANN, Medan, Indonesia \\ *Corresponding author E-mail: jannersimarmata@ unimed.ac.id
} Agung Purnomo ${ }^{4}$, Riesta Devi Kumalasari ${ }^{4}$, Fatkul Anam ${ }^{5}$, K Khoifulloh ${ }^{6}$, Khairun Nisa ${ }^{7}$, Yen Aryni ${ }^{7}$, Oktaviana

\begin{abstract}
Many children are currently challenging to comprehend the mathematics learning, especially the counting. The children assumed that mathematics is a disliked subject, while most of the aspects in the daily life require the ability to count. The primary education about the numbers is still lacking. In early childhood, a math learning activity should be in a fun atmosphere in learning. To know numbers need to be presented creatively by using media such as multimedia-based computers so as not to get bored for the students. The application of number recognition for early childhood is equipped with sound to assist the students in pronouncing the numbers. By using the computer, the students can recognize the number 1 to 10 increased by about $37 \%, 39 \%$ of the students can write the numbers, and $15 \%$ of them can say the numbers.
\end{abstract}

\section{Introduction}

Mathematics is a lesson that most children dislike. To draw children's interest and attention to the subject of mathematics, the learning styles presented should be designed in such a way as to be productive and enjoyable, not conventional. For early childhood, the learning should refer to the primary knowledge that playing by expertise and vice versa. The learning activities of mathematics need to create a fun atmosphere such as multimedia-based computers as the media [1]-[4].

The difficulties to understand the concept of numbers indicated a 5-year-old child needs guidance and supervision from both the parents and the teachers. Parents and teachers can do this through activities that are fun for children, for example through a variety of games related to the number. Parents or teachers can create a variety of games that can encourage children to learn to master the numbers. Learning can be done not only in the classroom but also outside the school [5]-[7]. The important thing is that the children feel happy and interested in activities to master the concept of the number. Besides, parents or teachers should consider the level of the students' ability or the children understands the material given. Piaget in his theory viewed that the children as individuals (learners) are active. Piaget's main attention focused on how the children can take a role in the environment and how it is influential on the mental development. According to Piaget, the child always interacts with the surrounding and still trying to overcome the problems it faces in that environment [8].

Learning is the effort to deliver information and resources to the recipient of the data[9], [10]. In the communication process often does not run smoothly because of an obstacle called 'Barriers to Effective Learning' in the form of misinterpretation, attention that is not centralized, the absence of comprehensive response and the disturbance of the physical state of the learning environment [11]. Based on the background of the problems that have been mentioned above, problems can be identified as follows: 1. The teacher has not created a pleasant atmosphere; it is evident from: a). Students do not focus on paying attention to learning steps, b). The learning procedure is not followed by all students in the class, c). The learning material is not optimally studied by the students 2 . The existing learning media is not optimally used in the learning process 3 . The results of student learning in the field of mathematics, especially in number recognition for early childhood have not been optimal.

Counting and recognizing the numbers are 2 (two) things needed in everyday life. All aspects of daily life must require the ability to count. Therefore counting has become a necessity that must be owned by everyone to live every day comfortably. For that reason, every child should be taught early to know the numbers 
and count so that they are secure in the future. The steps to introduce the numbers and to count for the children are the two methods, namely: The first method: teaching the concept of counting, memorizing the numbers, recognizing the numbers, and interacting with numbers.

\section{Basic Theory}

\subsection{Learning Media}

Generally, learning media is a tool in teaching and learning process. Everything that can be used to stimulate the mind, feeling, attention and ability or skills of learners encourages the learning process [12]-[15]. This scope is broad and deep covering the notion of the source, environment, human and methods utilized for learning or training purposes. Meanwhile, according to Gagne \& Briggs, learning media is a physical means to deliver content/learning materials such as books, movies, videos and so forth [16].

There are several types of learning media, including a). Visual Media: graphs, charts, posters, cartoons, comics; b). Audio Media: radio, tape recorder, language laboratory, and the like; c). Projected still media: slide; overhead projector (OHP), in focus and the like; d). Projected motion media: movies, television, video (VCD, DVD, VTR), computers and the like. Learning media can be said to be useful if it has fulfilled some characteristics.

\subsection{Multimedia}

Multimedia is a medium that combines two elements or more media consisting of text, graphics, images, photos, audio, video, and animation in an integrated manner. Multimedia is divided into two categories, namely: linear multimedia and interactive multimedia. Interactive multimedia is multimedia equipped with user-operated controller tools, so the users can choose what they want for the next process. Examples of interactive multimedia are interactive learning multimedia, game apps, etc. While learning is defined as the process of creating an environment that allows the learning process. A personal computer (PC) can be said to be a multimedia PC if it has: a CD-ROM or DVD drive [17], [18]. It supports the recording and playback of 16-bit wavelength audio, MIDI sound synthesis, MPEG moving image display, a reasonably fast center and a large enough RAM capable of playing and interacting with these media in real time, and with hard drives large enough to store the created multimedia work [19].

\section{Method of Development}

The Research and Development of the ADDIE generally divide the method of development into 5 (five) crucial stages, i.e. from problem analysis to the test phase and application socialization, arranged gradually in the form of diagrams as can be seen from figure 1 below:

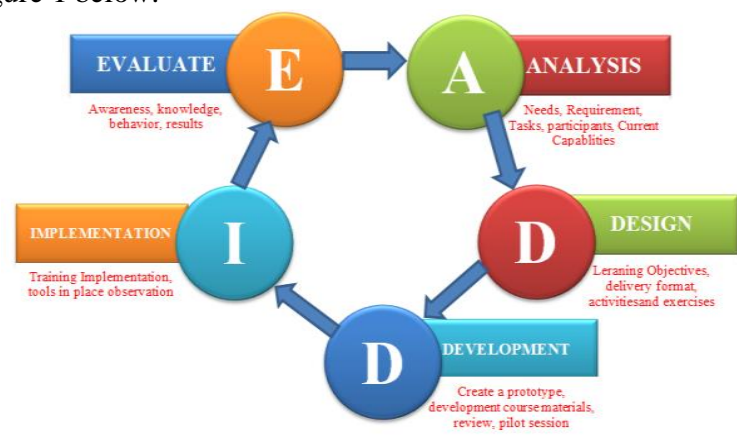

Fig 1. Method of Development: ADDIE Learning Media
The techniques of data collection in the evaluation monitoring consist of (1) open and in-depth interviews; (2) direct observation/observation; and (2) written documents. The target that becomes the observations for monitoring activities of this evaluation includes the process of learning in the classroom (school) to reveal the data about the learning process in schools and study groups and the availability of educational facilities and infrastructure in schools about teaching materials and media in recognizing the numbers. While the documents used in the study is the archive of evaluation of learning outcomes and other written data deemed necessary.

\section{Result and Discussion}

\subsection{Results}

The form of learning application using a computer has been tested directly for three consecutive days in two classes of current manual and one class by using the computer as in the display the following images:

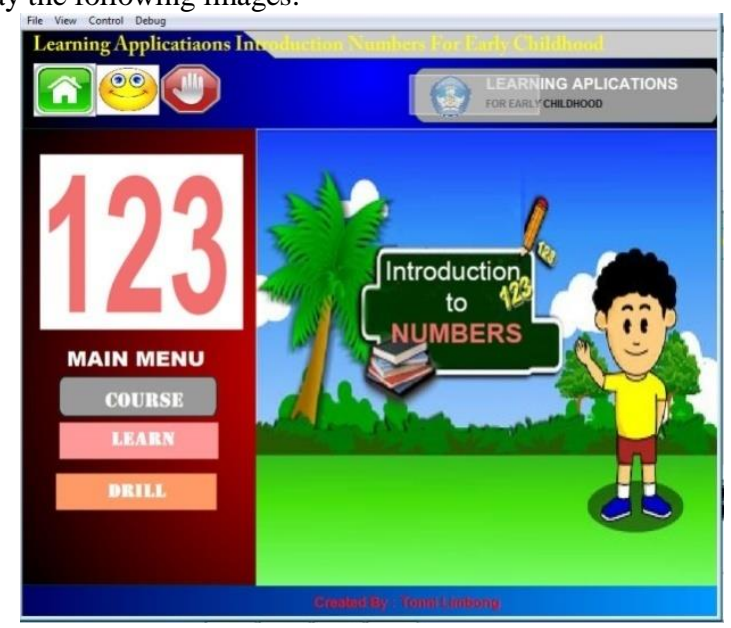

Fig 2. Main Menu

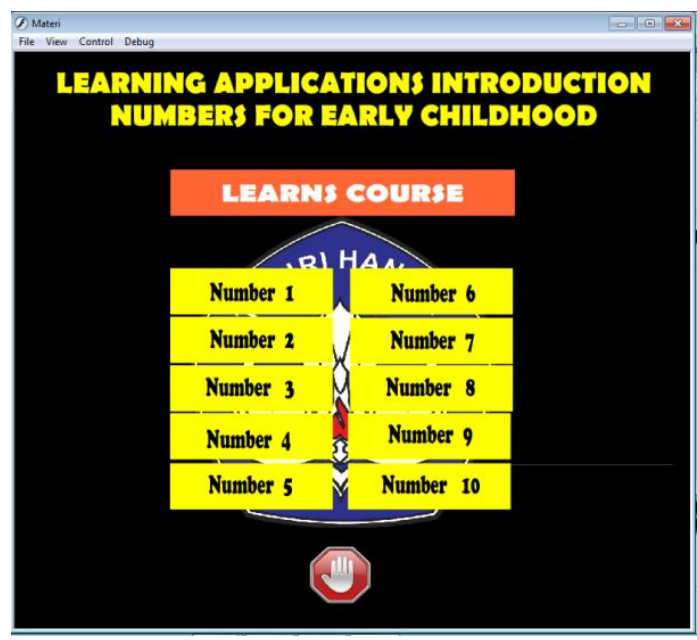

Fig 3. Main Menu of Material 


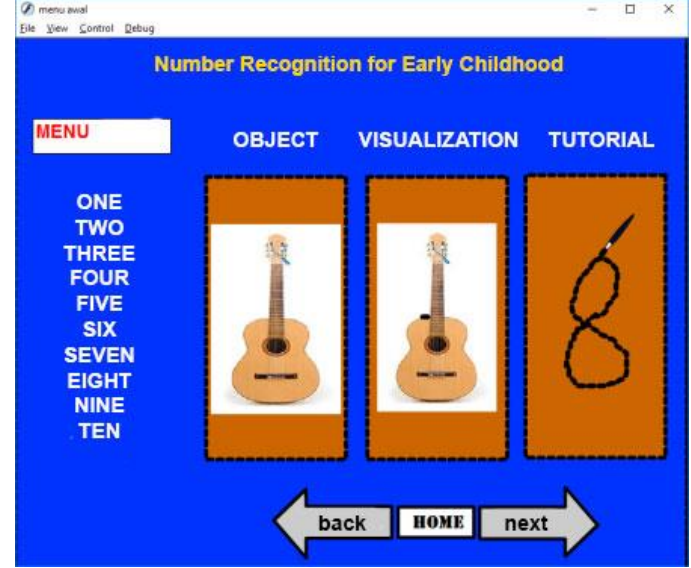

Fig 4: Display of Learning Menu

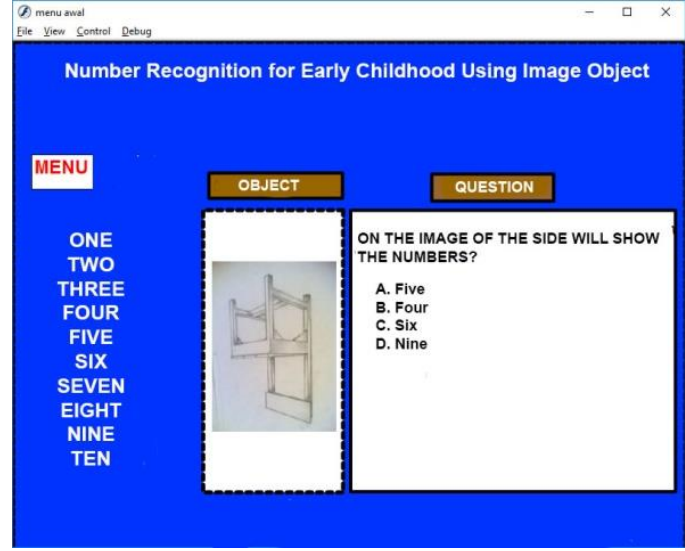

Fig 5. Display of Evaluation Menu

\subsection{Discussion}

The data analysis used is quantitative descriptive analysis, that is by describing and interpreting data from each indicator component of context, input, process and product/output evaluated. The data is analyzed descriptively quantitative by presenting the result of the detailed statistical calculation in the form of frequency table and percentage obtained from monitoring evaluation results.

Each learning process that is implemented obtained the results or targets to achieve that is the achievement of children in recognizing the numbers. The effects of data collection on the use of the Application Learning Numbers in Early Childhood utilize Images in 2 classes (manual and computer) with the number of different students as in the following graph:

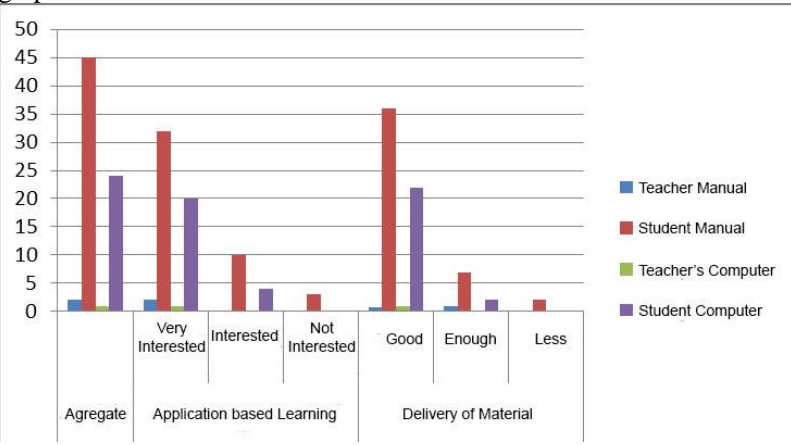

Fig 6. Survey Results of Number Recognition Learning Using Application

\section{Conclusions}

Multimedia-based computer learning applications are helpful in understanding about pronouncing numbers, writing and getting to know images that can visualize a number. The target is the ability of the students to understand the material. This application also envisions the creation of numbers so that students can quickly recognize and write down the numbers. This application is also equipped with sound to assist students in pronouncing the number. With the use of the computer, the students can recognize the number from 1 to 10 increased by about $37 \%$, write $39 \%$ and say $15 \%$. Teachers also need to get training to use the computer as a medium of learning as an alternative in educating students to recognize numbers and writing and saying. It also motivates the learners to feel interested and not easily bored.

\section{References}

[1] J. Simarmata et al., "Learning Application of Multimedia-BasedComputer Network Using Computer Assisted Instruction Method," Int. J. Eng. Technol., vol. 7, no. 2.13, pp. 341-344, Apr. 2018.

[2] S. Sriadhi, S. Gultom, R. Restu, and J. Simarmata, "The Effect of Tutorial Multimedia on the Transformator Learning Outcomes Based on the Students, Visual Ability The Effect of Tutorial Multimedia on the Transformator Learning Outcomes Based on the Students, Visual Ability," IOP Conf. Ser. Mater. Sci. Eng. $384012059,2018$.

[3] T. Limbong et al., "The Implementation of Multi-Objective Optimization on the Basis of Ratio Analysis Method to Select the Lecturer Assistant Working at Computer Laboratorium," Int. J. Eng. Technol., vol. 7, no. 2.13, pp. 352-356, Apr. 2018.

[4] J. Simarmata et al., "Prototype Application Multimedia Learning for Teaching Basic English," Int. J. Eng. Technol., vol. 7, no. 2.12, pp. 264-266, Apr. 2018.

[5] J. Simarmata, A. Djohar, J. P. Purba, and E. A. Djuanda, "Implementasi Model Pembelajaran Berbasis Blended Learning Untuk Meningkatkan Hasil Belajar Siswa."

[6] J. Simarmata, A. Djohar, J. P. Purba, and E. A. Djuanda, "Perancangan Prototype Model Pembelajaran Berbasis Blended Learning Untuk Meningkatkan Proses Pembelajaran,” 2017.

[7] N. B. S. Wangi et al., "Gamification Framework and Achievement Motivation in Digital Era: Concept and Effectiveness," Int. J. Eng. Technol., vol. 7, no. 3.6, pp. 429-431, Jul. 2018.

[8] J. Piaget and M. Cook, The origins of intelligence in children, vol. 8, no. 5. International Universities Press New York, 1952.

[9] S. Sriadhi, R. Rahim, and A. S. Ahmar, "RC4 Algorithm Visualization for Cryptography Education," J. Phys. Conf. Ser., vol. 1028, no. 1, p. 012057, Jun. 2018.

[10] K. Adiyarta, D. Napitupulu, R. Rahim, D. Abdullah, and M. Setiawan, "Analysis of e-learning implementation readiness based on integrated elr model," J. Phys. Conf. Ser., vol. 1007, no. 1, p. 012041, Apr. 2018.

[11] R. Rahim et al., "Internet based remote desktop using INDY and socket component," Int. J. Eng. Technol., vol. 7, no. 2.9, pp. 4447, 2018.

[12] D. Napitupulu et al., "Analysis of Student Satisfaction Toward Quality of Service Facility,” J. Phys. Conf. Ser., vol. 954, no. 1, p 012019, Jan. 2018

[13] J. Simarmata, A. Djohar, J. Purba, and E. A. Juanda, "Design of a Blended Learning Environment Based on Merrill's Principles," $J$. Phys. Conf. Ser., vol. 954, no. 1, 2018.

[14] N. Nasrudin, I. Agustina, A. Akrim, A. S. Ahmar, and R. Rahim, "Multimedia educational game approach for psychological conditional," Int. J. Eng. Technol., vol. 7, no. 2.9, pp. 78-81, 2018.

[15] E. Kartikadarma, T. Listyorini, and R. Rahim, "An Android mobile RC4 simulation for education," World Trans. Eng. Technol. Educ., vol. 16, no. 1, pp. 75-79, 2018.

[16] R. M. Gagne and L. J. Briggs, Principles of instructional design. Holt, Rinehart \& Winston, 1974.

[17] G. Gunawan et al., "Mobile Application Detection of Road Damage using Canny Algorithm," J. Phys. Conf. Ser., vol. 1019, no. 1, p. 012035, Jun. 2018.

[18] J. Simarmata, "Pengenalan Teknologi Komputer dan Informasi," Yogyakarta Andi, 2006.

[19] J. Simarmata and T. Chandra, "Grafika Komputer," Yogyakarta Penerbit Andi, 2007. 